\title{
Fibrosing mediastinitis-related pulmonary artery and vein stenosis-limiting chemotherapy
}

\author{
Michael Lawrenz Ferreras Co, ${ }^{1}$ Hena N Patel, ${ }^{2}$ Arianne Clare Agdamag, ${ }^{2}$ \\ Tochukwu M Okwuosa²
}

\begin{abstract}
'Department of Medicine, Rush University Medical Center, Chicago, Illinois, USA IInternal Medicine-Cardiology, Rush University Medical Center, Chicago, Illinois, USA
\end{abstract}

\section{Correspondence to}

Dr Michael Lawrenz Ferreras Co, michael_co@rush.edu

Accepted 1 April 2018

\section{DESCRIPTION}

A 74-year-old woman presented for second opinion of dyspnoea management. Her medical history included breast cancer treated with mastectomy, doxorubicin, cyclophosphamide and tamoxifen. She developed recurrent metastatic disease in the mediastinum, managed with 89 six-week cycles of paclitaxel over 10 years that was well tolerated and effective in stabilising the disease initially but eventually discontinued due to new sternal metastasis diagnosed on imaging and increasing dyspnoea. Examination revealed diminished left-sided breath sounds. Routine labs were normal. Echocardiogram showed normal left ventricular function and dilated right chambers. Repeat chest CT demonstrated: (1) extensive calcification and soft tissue mass in the anterior mediastinum consistent with fibrosing mediastinitis (FM); (2) severe left pulmonary artery stenosis (PAS, figure 1); and (3) an infiltrating soft tissue density in the pericardium. Subsequent pericardial tissue biopsy showed non-specific fibrosis. Pulmonary angiography showed bilateral PAS. Angiographic and surgical interventions were deferred due to the extent of the mediastinal fibrosis and overall poor prognosis. Repeat imaging

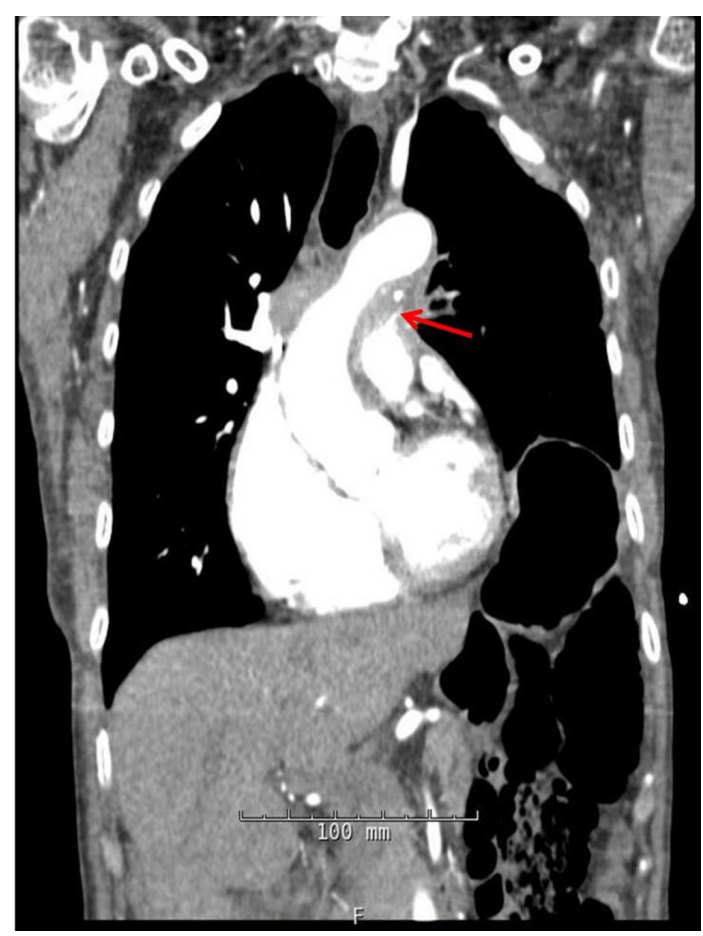

Figure $1 \mathrm{CT}$ chest showing severe left pulmonary artery stenosis.

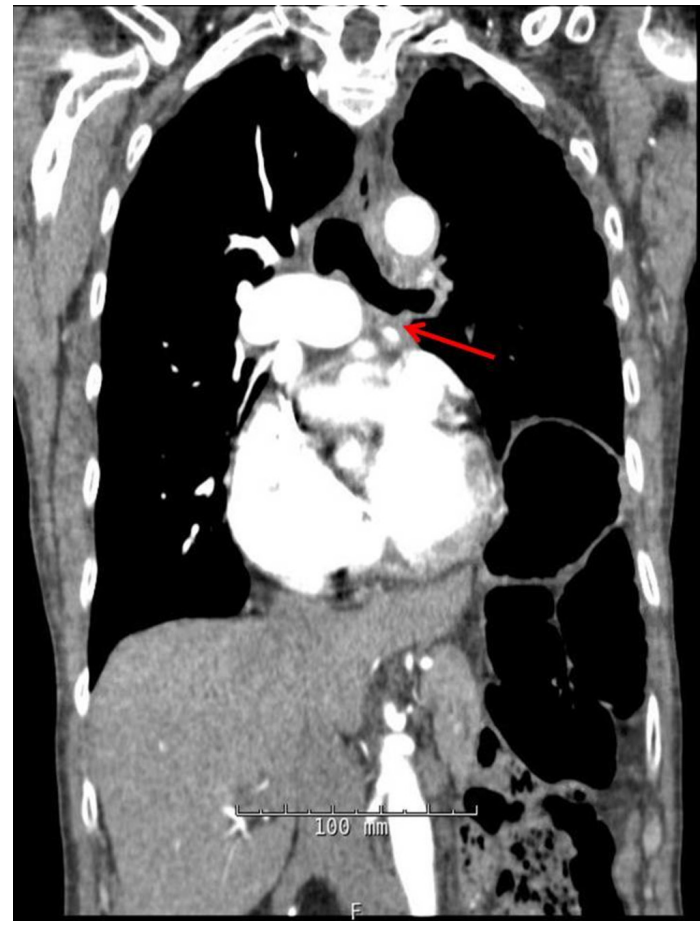

Figure 2 Repeat CT several months later showing stenosis of the left pulmonary vein.

showed progression of FM with new left pulmonary vein stenosis (figure 2 ), leading to a multidisciplinary decision to pursue palliative care. Palliative hormonal therapy was subsequently initiated.

FM is a rare disorder characterised by fibrous tissue proliferation within the mediastinum leading to disabling symptoms or death with compression

Learning points

- Fibrosing mediastinitis (FM) should be considered in any patient who underwent chemotherapy and has dyspnoea.

- Paclitaxel, one of the commonly used chemotherapeutic drugs for metastatic breast cancer, may be associated with FM despite its known low pulmonary toxicity profile.

- Complications of FM, like pulmonary artery stenosis and pulmonary vein stenosis, can be potentially chemotherapy limiting and need to be addressed promptly. Pulmonary artery stenting or surgical repair could be considered; however, early diagnosis and intervention prior to extensive mediastinal fibrosis is paramount. 
of surrounding structures. ${ }^{1}$ Paclitaxel and cyclophosphamide are associated with pulmonary fibrosis and may also be associated with FM like other chemotherapeutic agents, including bleomycin (most commonly), busulfan, carmustine and gemcitabine; with incidences ranging from $1 \%$ to $10 \% .^{23}$ A multidisciplinary approach to treatment, which includes screening and early intervention, may be key to management of these cases.

Contributors All four authors contributed towards the creation of the report. MLFC was involved in writing up the majority of the case and image acquisition. HNP was involved in conceptualisation of the approach, obtaining consent and editing. ACA was involved in literature review and image editing. TMO, the advisor, came up with the initial idea, conceptualisation of the approach and editing the final report.

Funding The authors have not declared a specific grant for this research from any funding agency in the public, commercial or not-for-profit sectors.
Competing interests None declared.

Patient consent Not required.

Provenance and peer review Not commissioned; externally peer reviewed.

(C) BMJ Publishing Group Ltd (unless otherwise stated in the text of the article) 2018. All rights reserved. No commercial use is permitted unless otherwise expressly granted.

\section{REFERENCES}

1 Rossi SE, McAdams HP, Rosado-de-Christenson ML, et al. Fibrosing mediastinitis. Radiographics 2001;21:737-57.

2 Ostoros G, Pretz A, Fillinger J, et al. Fatal pulmonary fibrosis induced by paclitaxel: a case report and review of the literature. Int I Gynecol Cancer 2006;16(Suppl 1):391-3.

3 Schwaiblmair M, Behr W, Haeckel T, et al. Drug induced interstitial lung disease. Open Respir Med J 2012:6:63-74.

Copyright 2018 BMJ Publishing Group. All rights reserved. For permission to reuse any of this content visit http://group.bmi.com/group/rights-licensing/permissions.

BMJ Case Report Fellows may re-use this article for personal use and teaching without any further permission.

Become a Fellow of BMJ Case Reports today and you can:

- Submit as many cases as you like

- Enjoy fast sympathetic peer review and rapid publication of accepted articles

- Access all the published articles

- Re-use any of the published material for personal use and teaching without further permission

For information on Institutional Fellowships contact consortiasales@bmjgroup.com

Visit casereports.bmj.com for more articles like this and to become a Fellow 